\title{
The potential of an educational institution in the preparation of future specialists in the service sector for entrepreneurship
}

\author{
V. Maikovska \\ Kharkov Trade and Economic Institute of KNTEU, Kharkov \\ A. S. Makarenko Sumy State Pedagogical University, Sumy, Ukraine \\ Corresponding author. E-mail: maykovska@ukr.net
}

Paper received 29.04.20; Accepted for publication 16.05.20.

\begin{abstract}
https://doi.org/10.31174/SEND-PP2020-229VIII93-08
\end{abstract}
\begin{abstract}
The publication raises the question of the essence and content of the educational institution's potential in preparation of future specialists service sphere's to entrepreneurship. The article examines the results of finding the grounds for choosing the directions of entrepreneurial competence's formation. The analysis of the level's formation of moral, ethical, professional-business and communicative blocks of personality future specialists service sphere's. The reasons for students' unpreparedness for active entrepreneurship were evaluated. As a result, the classification revealed pedagogical conditions, the creation of which ensures the formation of entrepreneurial competence.
\end{abstract}

Keywords: entrepreneurship, entrepreneurial activity, entrepreneurial competence, the potential of an educational institution, pedagogical conditions, methodological and technological means.

Introduction. Today's economy needs highly skilled professionals able to solve complex problems in a market environment. Therefore, a competent specialist must have three main characteristics, which were emphasized by V. Lozovecz'ka and others: 1) workplace efficiency (productivity and quality of work, ability to adapt, ability to contribute to the achievement of the overall goals of a company, desire for safety and environmental protection; 2) mobility (flexibility, diversity, focus on selfimprovement and learning); 3) development of personal qualities which are necessary for successful work, horizontal and vertical movement [1, p. 65]. The urgency of the problem of preparation for entrepreneurial activity is conditioned by the presence of a dispute identified during the study, to which E. Serebrennikova drew attention: between the objective need of the society for young specialists, capable of making business initiating, qualifiedly, creatively, responsible, and the lack of a sufficient number of graduates, who are competent in this field [2, p. 36]. In conditions of market relations, entrepreneurial activity greatly influences the development of the national market of services, deepening of competition, increasing the level of employment of the country population. We agree with E. Serebrennikova that preparation for entrepreneurship should be done within the single educational process by integrating the content of basic vocational and additional entrepreneurship education [2, p. 37]. According to D. Meshherjakov (with who we agree), the structure of entrepreneurial competence is functional [3, p. 49], so it is impossible to organize vocational training without analyzing the professional activity of a future specialist. It includes identification of production functions and typical tasks, creating the system of knowledge and skills, as V. Lozovecz'ka and others have offered [1]. The need for this task to be done leads to a rethinking of conceptual and methodological approaches to using an educational institution's potential during the preparation of future service sector specialists to entrepreneurship.

Analysis of sources by research topic. The author's vision of ways to solve the problem is based on the interpretation of results of the scientific works of A. Alexiuk, V. Andrushchenko, M. Vilensky, O. Gluzman, N. Demyanenko, N. Efremova, S. Kvartalnov,
G. Kovalchuk, G. Kozlakova, B. Korolev, K. Korsak, V. Kremen, V. Lunyachek, V. Mayboroda, V. Manko, N. Nichkalo, V. Radkevich, M. Stepko, V. Strelnikov, O. Yaroshenko, and others. Among Ukrainian economists, who are engaged in scientific and theoretical substantiation of the essence of entrepreneurship as a social phenomenon, it is worth noting L. Bezchasny, V. Bordyuk, Z. Varnaliy, V. Heitz, V. Golikov, V. Rybalkin, V. Savchuk, O. Turchynov, and others. The issue of entrepreneurship of citizens as one of the leading condition of implementation of reforms and a significant sign of society's renewal has become the object and subject of research of A. Ageev, V. Bespalov, R. Brockhaus, A. Gelbak, V. Kuzin, A. Omarov, R. Khizrich, and others. M. Tkachenko figured out that foreign researchers (W. James, R. Macho, M. Molt, D. Ray, M. Ron, etc.) and national scientists (A. Batarshev, A. Busygin, A. Karpov, L. Kotegov, V. Novikov, T. Obukhova, A. Smirnov, M. Tutushkin) have conducted investigations the main purpose of which was to identify and characterize the qualities that are decisive for an entrepreneur's activity [4]. According to G. Matukova that national scientists who have studied the personality of the entrepreneur as a participant in the labor market are V. Bazilevich, O. Vlasyuk, S. Vovkanych, A. Galchinsky, A. Kredisov, A. Kinakh, M. Mikhalchenko, Y. Pakhomov, V. Pylypenko, I. Prokopenko, V. Seminozhenko, A. Chukhno, I. Shevel, and others. [5]. We can not ignore the achievements of P. Ignatovsky, who sees the solution to the main problem of Ukrainian society's development in business culture development. The works of D. Zakatnov, A. Kolikhalova, D. Thorzhevsky, G. Shevchenko, V. Plakhuta, and others are devoted to this problem.

Among the researches that seem to us to be the most significant for solving the problem are papers of Y. Banita, M. Boyko, I. Gayovoy, V. Dryzhak, Y. Klipa, L. Kozachok, N. Kuryacha, O Lutsov, S. Melnik, M. Palchuk, N. Pasichnyk, N. Pobirchenko, A. Putintsev, N. Pokatilovsky, T. Prutskaya, O. Semenyuk, T. Stakhmach, M. Tkachenko, O. Shcherbak, and others. There, the researchers substantiate the need for the formation of a complex of knowledge, special skills, and 
ways of entrepreneurial activity realization; a set of relevant business, moral and personal qualities; they emphasize the importance of balancing the theoretical and practical components of the process of young people preparation for entrepreneurship. From our point of view despite numerous publications, the problem of an educational institution's potential in preparing future service sector professionals for entrepreneurship is not fully understood. So, the question of an educational institution's potential in preparing future service sector professionals for entrepreneurship is raised in a study whose results are reflected in the paper.

Purpose of the Study. The purpose of the paper is to study the nature and content of a higher education institution's potential in preparing future service sector specialists for entrepreneurship and to analyze the effectiveness of its use during the formation of entrepreneurial competence as one of the key competencies of future professionals in Ukraine.

Materials and Research Methods. The research based on Kharkov Trade and Economic Institute of KNTEU with including students and teachers. In the research process were used methods direct analysis of content on the problem, observation, survey, comparison; analysis and synthesis of the results.

Results and its discussion. The modern world is characterized by processes of globalization and internationalization of the economy and an increase in labor migration. We, therefore, agree with V. Vorona that this fact affirms the key role of higher education in the preparation of a competent specialist who adapts quickly to economic, social, and cultural changes [6]. Adoption of Law of Ukraine "On Higher Education" [7] directs its efforts to increase the effectiveness of specialists professional training by education content updating and bringing it into line with society and an individual's needs. At the same time, researchers of the problem, including E. Serebrennikova [2, p. 38], emphasize that the graduate becomes a competent expert not only in the obtained specialty but also in the case of his/her preparation for market relations by creating appropriate conditions and attracting appropriate resources. Such an approach makes it possible to speak about the potential of an educational institution as a set of all available opportunities and means in future service sector specialists preparation for entrepreneurship [8].

Talking about the problem of an educational institution potential in general or an institution of higher education (HEI) in particular, we refer to the "circumstances in which the components of the educational process are presented in the best connection", "a set of external and internal influences" and "a set of specially designed general factors of influence on the external and internal circumstances of the educational process and the personal parameters of all its participants, which ensure the education and upbringing integrity". However, these definitions in the understanding of V. Manko and V. Polonsky (quoted by O. Slobodyanyuk) [9, p. 100] and O. Matseiko (cited by M. Tkachenko [4, p. 118]) relate precisely to pedagogical conditions, which creates an opportunity to consider pedagogical conditions as an essential component in the structure of an educational institution.
The results of the teachers' survey show that $100 \%$ of respondents believe students are ready for independent professional activity upon graduation. At the same time, $83,4 \%$ of the teachers consider that just graduated specialists are unprepared for independent entrepreneurship. The rating of the revealed reasons for unpreparedness is as follows: 1) excess theorization of knowledge in the learning process - $100 \%$; 2) lack of teachers practical readiness for preparing students for entrepreneurship - 83,1\%; 3 ) the weak correlation between the theoretical and practical components of the training, or the complete lack of it $68,1 \%$; 4) lack of practical component of preparing students for entrepreneurship - 67,3\%; 5) lack of communication between students and entrepreneurs in the educational process $-66,7 \%$; 6) absence in the educational process of analyzing real business problems and making suggestions for their solution $-65,9 \%$; 7) lack of a holistic interdisciplinary picture of preparing students for entrepreneurship - 33,8\%; 8) lack of teachers professional readiness for preparing students for entrepreneurship $16,4 \%$; 9) lack of teachers readiness for use forms and methods of interactive interaction in the educational process - 15,2.

None of the interviewed teachers questioned the psychological readiness of scientific and pedagogical staff for preparing students for entrepreneurship, and $17,1 \%$ of respondents indicated poor professional language training among other reasons for their lack of readiness.

The obtained results are contrary to the other which were gained in rating the importance of HEI actions in shaping youth entrepreneurial competence. According to the estimations of the same teachers, the first place belongs to HEI activities aimed to acquire basic knowledge of entrepreneurship by the student; the second place belongs to HEI activity aimed student practical preparation for entrepreneurship and the third place belongs to HEI activity aimed to student's personality development through entrepreneurship. The given example allows stating a lack of clear understanding of the problem essence among teachers. At the same time, students have another point of view: $70,4 \%$ believe that it is possible to prepare them for entrepreneurship in classes in different disciplines, including "Fundamentals of Entrepreneurship". $65,1 \%$ of respondents see the way of preparation for entrepreneurship in participation in competitions, championships, and other events with entrepreneurial topics. Thus, the problem of HEI potential was transformed into the problem of choosing methods and technological means of preparation.

The difference between students' and teachers' points of view caused the need for didactic taxonomization of the main characteristics of entrepreneurial competence. As a result, the leading directions of purposeful educational activity were identified on the basis of expert evaluations. The basis for the expert evaluation were two fundamental points - relevance and reach. The essence of the first criterion was to distinguish from the offered list those characteristics that were the most significant for the entrepreneur since their deficiency is particularly acute in today's socio-economic environment. The second criterion was the ability of students to acquire these characteristics within the educational process. As a result of expert evaluation processing, we identified three blocks of fea- 
tures and characteristics that received the highest ranks: moral and ethical, professional and business, communicative. On this basis, it is concluded that the educational process and the future service sector` specialists` training for entrepreneurship should be carried out in three main areas: moral and ethical, professional and business, and communicative. These areas are identified as leading educational lines of the HEI training process.

During the study, the moral and ethical unit was evaluated by the method of diagnostics of the social and psychological attitudes of an individual within the motivational and need sphere (using the test of O. F. Potemkina test) [10]. The quality of communication preparation was determined on the basis of the students' self-assessment of their own presentation abilities, and the level of profes- sional and business preparation was determined by the questionnaire results.

The results of the study in the moral and ethical direction showed that only $17,1 \%$ of students were ready for the role of a social entrepreneur, provided the involvement of other people; $32,8 \%$ of students were typical employees, about a half of whom $(16,4 \%)$ had "careerclimber" traits; the other $50,1 \%$ did not show any signs for clear demarcation. The level of quality of communicative preparation according to the results of students' selfassessment of their own presentation abilities testifies its age coloring: it is traced that the level growth from junior to senior courses, which is conditioned by the mastering of philological disciplines and gaining the public speaking experience during the studying [11, p. 204].

Table 1. Results of detection of the presentation skills level based on students' self-esteem

\begin{tabular}{|l|c|c|c|}
\hline \multicolumn{1}{|c|}{ Self-assessment statements of respondents } & \multicolumn{2}{|c|}{ Number of statements «rather yes», \% } \\
\cline { 2 - 4 } & $\begin{array}{c}\text { The first (bachelor) level } \\
\text { of higher education, the } \\
\text { third year }\end{array}$ & $\begin{array}{c}\text { The first (bachelor) level } \\
\text { of higher education, the } \\
\text { fourth year }\end{array}$ & $\begin{array}{c}\text { The second (master) } \\
\text { level of higher educa- } \\
\text { tion, the first year }\end{array}$ \\
\hline $\begin{array}{l}\text { I have an experience in public speaking and } \\
\text { presentations }\end{array}$ & 63,7 & 65,1 & 100,0 \\
\hline $\begin{array}{l}\text { I understand quickly the audience mood, its } \\
\text { willingness to perceive the performance }\end{array}$ & 83,2 & 70,9 & 71,4 \\
\hline $\begin{array}{l}\text { Capable of making the audience interested in } \\
\text { my words and actions }\end{array}$ & 50,6 & 55,3 & 71,4 \\
\hline $\begin{array}{l}\text { My language is logical, competent, bright and } \\
\text { figurative }\end{array}$ & 52,8 & 61,4 & 72,3 \\
\hline $\begin{array}{l}\text { I am able to use non-verbal means during a } \\
\text { speech }\end{array}$ & 48,5 & 71,7 & 85,7 \\
\hline
\end{tabular}

Source: Author`s survey.

The results of defining the role of academic disciplines in the context of future service sector specialists ' preparation for entrepreneurship (professional-business direction) in different panels are different too. Students have the next rating of importance: "Marketing" (94,7\%), "Fundamentals of Entrepreneurship" (91,3\%), "Management" $(85,1 \%)$, "Information Systems and Technologies" (79,9\%), "Economic Theory" (75,3), "Business Law" $(48,7 \%)$, "Other Disciplines" at the discretion of the respondents, including "Fundamentals of Leadership," "Accounting", "Discipline and Ethics of the Entrepreneur", "Basics of standardization, metrology and certification" $(33,1 \%)$. Here are results of the teachers` survey: "Fundamentals of Entrepreneurship" (51,9\%), "Information Systems and Technologies" (49,8\%), "Management" (48,3\%), "Business Law" (33,8\%), "Marketing" (32,6\%), "Other disciplines" at the discretion of the respondents, including "Economic theory", "Business Law", "Accounting", "Business Planning" (52,5\%).

Taken together, the results of the study lead to the conclusion: students attach greater importance to the motivational and value sphere and psychological portrayal of the future specialist as a subject of entrepreneurial activity, teachers - the cognitive aspect. According to the abovementioned results of the study, we can talk about the theoretical and practical components of the process of future professionals preparing for entrepreneurship. The theoretical component should be considered as the process of gaining professional mastery at the entrepreneurial background, the practical component should be considered as the formation of a specialist's personality readiness for conducting an entrepreneurial activity. Thus, the
HEI potential should ensure both the development of personal qualities and personal abilities, and the techniques and technological means must take into account the socially significant and professionally significant functions of the future specialist, which can be grouped into cognitive, professionally important and professionally neutral. So, its essence, being agreed with M. Tkachenko, we define as the presence in HEI: 1) forms of the personally-oriented announcement for future specialists about the mechanisms and ways of preparation for entrepreneurship; 2) space for social and professional attempts; 3) personal meanings of the subjects of pedagogical activity concerning the preparation of young people for entrepreneurship [4, p. 127].

The analysis of psychological and pedagogical content and the generalization of this study results allowed substantiating the nature and content of the potential of the educational institution as a set of pedagogical conditions with their further classification.

The following were the subjective ones: the level of students' motivation for entrepreneurship; their emotionalpsychological and physical condition; conformity of the content and nature of the educational process to the individual characteristics of students; experience of organization of functioning business environment in HEI; participation of HEI in the implementation of the social order of the region.

Objective conditions are divided into organizationallyenvironmental and resource groups. Organizationallyenvironmental - this is the moral and psychological climate and the level of relationship dialogue in the HEI; student motivation system for entrepreneurship; availabil- 
ity and effectiveness of a system of communication between HEI, public and authorities; respect for the national, cultural and business traditions of region; participation of HEI in the life of the region and meeting the needs of its population. Resources conditions - material and technical, informational, and personnel support of the educational process, as well as opportunities for upgrading the level of qualification of scientific and pedagogical staff.

The content pedagogical conditions include the integration of education, science, and production within professional training; academic freedom and academic mobility; obligatory application of competency-based and authorial training programs. As motivational and meaningful pedagogical conditions we outlined: students' level of satisfaction with the educational process; their positive motivation for learning and entrepreneurship as a social phenomenon and a way of self-employment; orientation on the value of the entrepreneurial activity. As procedural and pedagogical conditions we defined the possibilities of the HEI in choosing the appropriate technologies and teaching methods, forms of students activity, means of preparation for entrepreneurship, including using applied software products. Organizational and pedagogical conditions include those that provide the formation of entrepreneurial competence in the process of organizing educational and professional and quasi-professional activities of students, creating conditions for students to gain professional experience and experience of entrepreneurial activity. Among the didactic conditions are interdisciplinary content and entrepreneurial orientation of the educational process; application of training methods and techniques that ensure the intellectual development of future service sector professionals; having a clearly planned system of preparation for business activity; implementation of a system of learning outcomes evaluation.

Psychologically-pedagogical conditions were considered as a set of means of the interaction of all participants of educational process; providing the directional development of an individual: personal qualities, which are inherent to entrepreneur, entrepreneurial type of thinking, formation of entrepreneurial position and behavior in society, formation of entrepreneurial culture; in addition, psychological and pedagogical support of the process of entrepreneurial competency formation. Socio-pedagogical conditions are conditions that designed to help students to acquire social experience and self-realization experience during the vocational training.
Conclusions. The presented results of the research made it possible to declare the relevance of the identified problem and to identify ways of it solving in the context of modernization and increasing the efficiency of the system of professional training of future specialists in the service sector. It is determined that according to the results of content analysis of the term "potential of an educational institution" this concept has a broad understanding and it can be interpreted as a set of pedagogical conditions and applied methodological and technological means of preparation. The results of the study prove the objectivity of the need for creation in HEI a special system of work for the preparation of future specialists in the service sector for entrepreneurial activity. The materials obtained during the research show the complexity and diversity of pedagogical conditions, generalized in their classifications, the creation of which should be the task of HEI for solving the identified problem: meaningful, motivational-semantic, procedural-pedagogical, organizational-pedagogical, didactic, social-psychological, psychological-pedagogical, subjective for each HEI, objective depending on the conditions of HEI functioning. The data presented by the results of the research underscore the exceptional importance of organizational-pedagogical and social-pedagogical conditions for the preparation of future specialists in the service sector for entrepreneurship.

Based on the understanding of an educational institution potential in the preparation of future service sector specialists to entrepreneurship as a set of pedagogical conditions and applied (in their context) methodological and technological means, we highlighted as the main factors of preparation: 1) optimization of the vocational education content on an entrepreneurial background; 2) review of organizational forms of education towards the international experience of non-formal and informal education; 3) professional improvement of the teachers' qualification in HEI in scientific and practically oriented directions; 4) psychological and pedagogical improvement of teachers' qualification in HEI in the entrepreneurial direction.

Not all aspects of the problem can be covered the paper. That is why we link further scientific research to the study of the connection of pedagogical conditions on the basis of the above-mentioned classification and the effective application within them of the appropriate methodological and technological means of preparing young people for entrepreneurship.

\section{ЛИТЕРАТУРА}

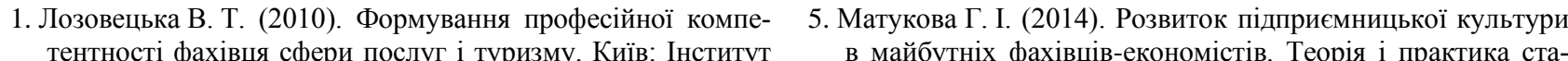
тентності фахівця сфери послуг і туризму. Київ: Інститут професійно-технічної освіти НАПН України, 382.

2. Серебренникова Е. А. (2012). Методологические подходы к формированию компетенций предпринимательской деятельности // Инновационное развитие профессионального образования, 36-38. URL: https://cyberleninka.ru/article/n/metodologicheskie-podhodyk-formirovaniyu-kompetentsiy-predprinimatelskoydeyatelnosti/viewer.

3. Мещеряков Д. А. (1999). Компетентность субъектов предпринимательской деятельности. Воронеж, 259.

4. Ткаченко М. В. (2018). Формування підприємницької компетентності майбутніх фахівців ресторанного господарства у професійно-технічних навчальних закладах. Київ, 347. новлення особистості в соціокультурному просторі: Монографія, 282-300.

6. Ворона В. А. (2018). Формирование профессиональной компетентности будущих специалистов в Украине как педагогическая проблема. Теоретико-методические основы внедрения компетентностного подхода в высшей школе: Монография, 29-47.

7. Закон України «Про вищу освіту» від 01.07.2014 № 1556VII. URL: http://vnz.ua/zakonodavstvo/111-zakon-ukrayinypro-vyshu-osvitu.

8. Потенціал. URL: https://uk.wikipedia.org/wiki/Потенціал.

9. Слободянюк О. М. (2017). Формування професійноетичної компетентності майбутніх менеджерів економічного профілю в процесі вивчення суспільно-гуманітарних 
дисциплін. Київ, 277.

10. Методика диагностики социально-психологических установок личности в мотивационно-потребностной сфеpe. Тест О. Ф. Потемкиной (2016). URL: https://hrportal.ru/tool/test-potemkinoy-diagnostika-socialno-

psihologicheskih-ustanovok-lichnosti-v-motivacionno.
11. Maikovska V., Semenog O. (2019). The communicative block as an important structural component of specialists' entrepreneurial competence in Ukraine // Proceding of $5^{\text {th }}$ International Conference. Фундаментальні та прикладні дослідження: сучасні науково-практичні рішення та підходи: № 5. URL: http://farcspsa.com/uk/фундаментальні-таприкладні-дослідж-2/. Р. 204.

\section{REFERENCES}

1. Lozovecz`ka, V. T. ed. (2010). Formuvannya profesijnoyi kompetentnosti faxivcya sfery` poslug i tury`zmu [Formation of professional competence of services sector' and tourism ' specialist]. Ky`yiv: Insty`tut profesijno-texnichnoyi osvity NAPN Ukrayiny`, 382.

2. Serebrennikova, E. A. (2012). Metodologicheskie podhody k formirovaniju kompetencij predprinimatel'skoj dejatel'nosti [Methodological approaches to the formation of competencies of entrepreneurial activity]. Инновационное развитие профессионального образования, 36-38. Available at: https://cyberleninka.ru/article/n/metodologicheskie-podhody$\mathrm{k}$-formirovaniyu-kompetentsiy-predprinimatelskoydeyatelnosti/viewer.

3. Meshherjakov, D. A. (1999). Kompetentnost' sub\#ektov predprinimatel'skoj dejatel'nosti [Competence of entrepreneurial entities]. Voronezh,. 259.

4. Tkachenko, M. V. (2018).

Formuvannya pidpry`yemny`cz`koyi kompetentnosti majbutnix faxivciv restorannogo gospodarstva $u$ profesijno-texnichny`x navchal'ny`x zakladax [Formation of entrepreneurial competence of future specialists of the restaurant industry in vocational educational institutions]. Ky`yiv, 347.

5. Matukova, G. I. (2014). Rozvy`tok pidpry`yemny`cz`koyi kul'tury` $v$ majbutnix faxivciv-ekonomistiv [The development of an entrepreneurial culture of future specialists-economists]. Teoriya i prakty`ka stanovlennya osoby`stosti v sociokul turnomu prostori: Monografiya, 282-300.

6. Vorona, V. A. (2018). Formirovanie professional'noj kompetentnosti budushhih specialistov $\mathrm{v}$ Ukraine kak pedagogicheskaja problema [Formation of professional competence of future specialists in Ukraine as a pedagogical problem]. Teoretiko-metodicheskie osnovy vnedrenija kompetentnostnogo podhoda v vysshej shkole: Monografiya, 29-47.

7. Zakon Ukrayiny` «Pro vy`shhu osvitu» vid 01.07.2014 № 1556-VII. Available at: http://vnz.ua/zakonodavstvo/111zakon-ukrayiny-pro-vyshu-osvitu.

8. Potencial. Available https://uk.wikipedia.org/wiki/Потенціал.

9. Slobodyanyuk, O. M. (2017). Formuvannya profesijnoety`chnoyi kompetentnosti majbutnix menedzheriv ekonomichnogo profilyu u procesi vy`vchennya suspil`nogumanitarny`x dy`scy`plin [Formation of professional-ethical competence of future managers of economic profile in the process of studying social and humanitarian disciplines]. Ky`yiv, 277.

10. Metodika diagnostiki social'no-psihologicheskih ustanovok lichnosti v motivacionno-potrebnostnoj sfere. Test O. F. Potemkinoj (2016). Available at: https://hrportal.ru/tool/test-potemkinoy-diagnostika-socialnopsihologicheskih-ustanovok-lichnosti-v-motivacionno. 